\title{
コンクリートの初応力についで*
}

大浜文彦**

\section{On the Initial Stresses in Concrete}

by

\author{
Fumihiko OHAMA \\ (Mie University)
}

This paper reports on the researches concerning the initial stresses in concrete.

At first, in order to predict the shrinkage and the initial stresses in concrete, the graphical and numerical computation are described. And then, as one of the measuring methods of the initial stress in concrete specimen that has been exposed to the air, procedures and results of the whittling and erasing methods are stated. Test results are in accordance also with the decrease of bending strength of the similar specimen.

In general, the intensity of the initial stress at the surface of the specimen is found to be about $20 \mathrm{~kg} / \mathrm{cm}^{2}$ (tension) in mortar, and about $15 \mathrm{~kg} / \mathrm{cm}^{2}$ (tension) in concrete.

(Received May 23, 1959)

\section{1. 緒 \\ 言}

コソクリート構造物では，乾燥や冷却などによって， 初応力 (Initial Stress) が発生し, 荷重が加わる以前 に，ある程度の応力が存在する。とくに，これらによ る容積变化の分布があれば，外的に变形が自由な場合 でも, コンクリート内部では局部的に容積変化が抑制 されて初応力を発生する。初応力と荷重による応力と の和が破壊応力をこえれば,き裂が発生する.初応力の 応力度が大であれば，それのみでもき裂を発生するが， 初応力の分布は, 普通, コンクリートでは, 表層での 勾配が急であって，き裂発生は，表層ごくわずかの部 分にとどまっていることが多い.しかし，このときで も，見かけ上，強度が低下する。したがって，なるべ く初応力を発生することの少ないコンクリートを用い ることが，き裂防止上大切である。

実際に生ずる初応力の推定に対しては，これまでの 研究では，まだ充分とはいいがたいので，著者は,.つ ぎの項目について基礎的な研究を試みた。

\section{A）初応力を発生する因子の研究}

従来の収縮応力, 熱応力のほかに, 加温を伴なった 乾燥湿潤の繰り返しによる応力を考え, その際の容積 变化(長さの変化)を実験的に追求した。また沈下収縮 や硬化収縮についても，実験ならびに考察を行なった。

\section{B) 初応力の解析と実測}

コンクリート内に容積変化が分布するとき, その連 続性を保つために变形が抑制されて, 初応力を生ずる

\footnotetext{
* 原稿受付 昭和 34 年 5 月 23 日

** 正員 三重大学農学部
}

のであるから, クリープを考虑しても，各瞬間では， 任意断面で初応力がつりあうものと考えれば, 初応力 の分布は, 構造力学的方法, または, 弾性学的解析に よって求められる.しかし，これによるときは，場合 によっては複雑な式となり，非実用的である.

著者は, 差分方程式やリラクセーション法を応用し， 数值解法を図解化して，とくに簡易なものとした。

また，実験的に初応力を発生させたはり状供試体の 初応力の測定法の一つと立てて, 曲げ試験における強度 の減少の観察と, 切削法をコンクリートに応用するこ とを試みた。

\section{C) コンクリート水路，その他の初応力の考察}

本研究を, 農業土木の主要構造物たるコンクリート 水路その他に応用した。

以上の各項のうち, 本稿では, 初応力の図解法と, コンクリート表層の初忘力の奉測について述べたいと 思う。

\section{2. 初応力の解析}

コンクリートの初応力では, 常に表層での引張り応 力が問題である。このように, 初応力を生ずるところ の冷却や乾燥による収縮の分布を数式で表現すること は, 厳密には非常に困難なことであるが, 若干の誤差 を実用上，ほとんどさしつかえない程度にとどめるも のとして，広くつぎの方程式が用いられている.

$$
\frac{\partial \varepsilon}{\partial t}=h^{2}\left(\frac{\partial^{2} \varepsilon}{\partial x^{2}}+\frac{\partial^{2} \varepsilon}{\partial y^{2}}+\frac{\partial^{2} \varepsilon}{\partial z^{2}}\right)
$$

ここに, $\varepsilon$ は収縮ひずみ, $t$ は時間, $x, y, z$ は直 交座標軸に関する座標, $h^{2}$ は冷却の場合は温度伝播率, 
乾燥の場合には，水分伝播率とよばれる係数で，ディ メンションは $L^{2} T^{-1}$ である。

表面における境界条件は，

$$
\lambda \frac{\partial \varepsilon}{\partial x}=\alpha \varepsilon
$$

ここで， $\lambda$ は熱伝導率， $\alpha$ は表面における熱伝達率， または, 水分の伝導率と表面における水分伝達率であ る。ただし，水分の伝導率として，単位面積が，単位 距離で相対し, 両面の含水率の差が, 館和水量に対し 1 パーセントであるとき，両面間を単位時間に移動す る水量を同じパーセントで表わせば，水分伝導率は， 水分伝播率と同じ值で示される。

コンクリートの収縮を左右するのは，セメントと半 ば結合して存在する半結合水である。コンクリート中 に含まれる水量のうち，約 $50 \%$ 前後を占める自由水 の放散が終った後, さらに乾燥して半結合水が放散し てはじめて認められるほどの収縮が現われる。この収 縮量は失われる半結合水の量にほぼ比例寺る。したが って，以上の水分伝導率，水分伝播率，ならびに，水 分伝達率などはいずれもこの半結合水に関する值であ る.

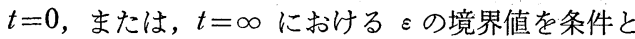
し, 式(1)，(2)を解いて，コンクリート体内の収縮 分布が求められる。

本論文では，有限微小量 $\Delta \varepsilon ， \Delta t$ を用いて計算する 階差方程式によるものとし，さらに簡単のため，厚さ 方向にのみ, 熱や水分が移動するところのスラブ中央 付近のみの収縮の分布を考えれば，式(1)，(2)はつ ざのようになる。

$$
\begin{aligned}
& \frac{\Delta \varepsilon}{\Delta t}=h^{2} \frac{\Delta}{\Delta x}\left(\frac{\Delta \varepsilon}{\Delta x}\right) \\
& \frac{\Delta \varepsilon}{\Delta x}=\frac{\alpha}{\lambda} \varepsilon
\end{aligned}
$$

いま，スラブ表面を $x=0$ とし，厚さの方向に $x$ 軸 をとり, 厚さ $D$ を $n$ 個の $\Delta x$ (微小量) で分割し, Fig. 1 のように, $0,1,2,3, \cdots \cdots, m, n$ を定める. 時 刻 $t$ のとさの点 $m$ のを $\varepsilon_{m}$ とする。ここで,

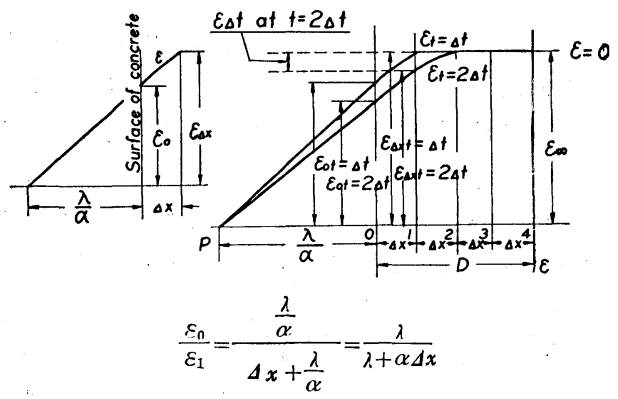

Fig. 1 Graphical computation of shrinkage distribution

$$
\Delta t=\frac{(\Delta x)^{2}}{2 h^{2}}
$$

とし,$\Delta t$ 間の $\varepsilon_{m}$ の増分を $\Delta \varepsilon_{m}$ (ただし， $m=1,2,3$, $\cdots \cdots n)$ とし， $m$ 点での $\varepsilon$ の勾配を， $m$ 点の前後で，

$$
\begin{aligned}
& \left(\frac{\Delta \varepsilon}{\Delta x}\right)_{+m}=\frac{\varepsilon_{m+1}-\varepsilon_{m}}{\Delta x} \\
& \text { および }\left(\frac{\Delta \varepsilon}{\Delta x}\right)_{-m}=\frac{\varepsilon_{m}-\varepsilon_{m-1}}{\Delta x}
\end{aligned}
$$

とすれば，式( 3 )より，

$$
\varepsilon_{m}+\Delta \varepsilon_{m}=\frac{1}{2}\left(\varepsilon_{+m+1}+\varepsilon_{m-1}\right)
$$

これは， $m$ 点の $t+\Delta t$ における $\varepsilon$ の值である.

さらに, Fig. 1に示すように,コンクリート表面Oよ $\eta, \lambda / \alpha$ の距離にある $x$ 軸上の点 $\mathrm{P} よ り$ 点 1 での $\varepsilon$ の 曲線に接する直線をひいて，これが $\mathrm{O}$ 点より点 1 まで の $\varepsilon$ 值を示すものとすれば， $\varepsilon_{0}$ は式 $(4)$ を満足する すなわち, 式( 4 )より, $\Delta \varepsilon=\varepsilon_{1}-\varepsilon_{0}, \varepsilon=\varepsilon_{0}$ とすれば,

$$
\begin{aligned}
\varepsilon_{0}= & \frac{\lambda}{\lambda+\alpha \Delta x} \varepsilon_{1}=\varphi \varepsilon_{1} \\
& \text { ただし, } \varphi=\frac{\lambda}{\lambda+\alpha \Delta x}
\end{aligned}
$$

以上の結果より, $t+\Delta t$ における $\varepsilon_{m}$ の值は, $t$ に おける $\varepsilon_{m-1}, \varepsilon_{m+1}$ の算術平均であること，および， $\varepsilon_{0}$ は常に $\varepsilon_{1}$ に $\varphi$ を乗じて求められることが明らかで ある。

したがって, $t=0$ における収縮の分布が与えられれ ば, $t=\Delta t, 2 \Delta t, \cdots \cdots$ における $\varepsilon$ の值は, 逐次的に求め られる。とに $t=0$ における $\varepsilon$ がコンクリート厚さ 全体にわたり一定値 $\varepsilon_{t=0}$ であるときは，逐次的に求め ることによる誤差を少なくするために，

$$
\begin{gathered}
{ }_{n} \mathrm{C}_{r}=\frac{n !}{(n-r) ! r !} \text { であるとき， } \\
{ }_{n} \mathrm{C}_{r}={ }_{n-1} \mathrm{C}_{r-1}+{ }_{n-1} \mathrm{C}_{r} .
\end{gathered}
$$

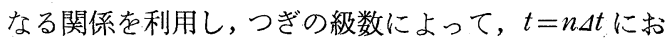

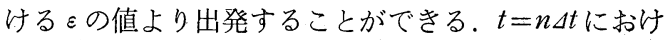
る $i$ 点 $\left(i \leq n, n, r\right.$ 整数)の $\varepsilon$ の值を $\varepsilon_{i n}$ とするとき, $n$ : 奇数

$$
\begin{aligned}
\varepsilon_{i n}=\frac{\varepsilon_{t=0}}{2^{n-1}}\left\{\sum _ { r = 0 } ^ { r = \frac { n - 3 } { 2 } } { } _ { n - 1 } \mathrm { C } _ { r } \left(\varphi^{n-\overline{i+2 r}}\right.\right. & \left.+\varphi^{n-\overline{i+2 r+1}}\right) \\
& \left.+{ }_{n-1} \mathrm{C}_{\frac{n-1}{2}}\right\}
\end{aligned}
$$

$n$ : 偶数

$$
\varepsilon_{i n}=\frac{\varepsilon_{t=0}}{2^{n-1}} \sum_{r=0}^{r=\frac{n}{2}-1}{ }_{n-1} \mathrm{C}_{r}\left(\varphi^{n-\overline{i+2} r}+\varphi^{n-\overline{i+2} \overline{r+1}}\right)
$$$$
\text { ただし， } \varphi^{0}=\varphi^{-1}=\varphi^{-2}=\cdots \cdots=1 \text { とする. }
$$

収縮の分布が求められだと，Fig. 2 に示すように， 原断面位置に平行で, $\varepsilon$ の平均值を示す面は, 曲がり のみが抑制されたとさの原断面の变位後の位置である。 このときの初応力の分布は, $\varepsilon$ 曲線と変形後の断面と の間にはさまれる抑制された变形に弾性係数を乗じた 


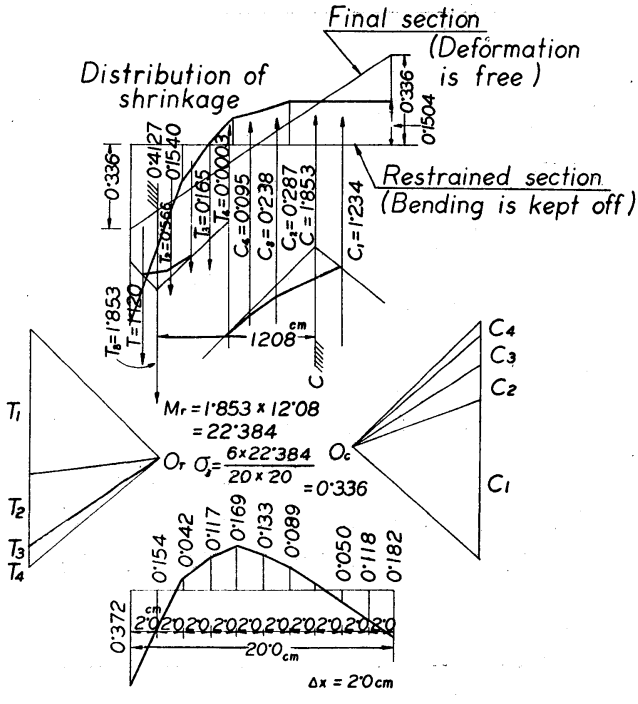

Note : $E_{c} \cdot \varepsilon_{\infty}=1$

Fig. 2 Graphical computation of initial stress (considered elastic)

\section{ものである}

さらにこの抑制力が生ずる断面曲げモーメントに 等しいだけの曲げモーメントを加えれば，曲がりも自 由とし，その断面の变位を完全に許したときの初応力 が求められる.

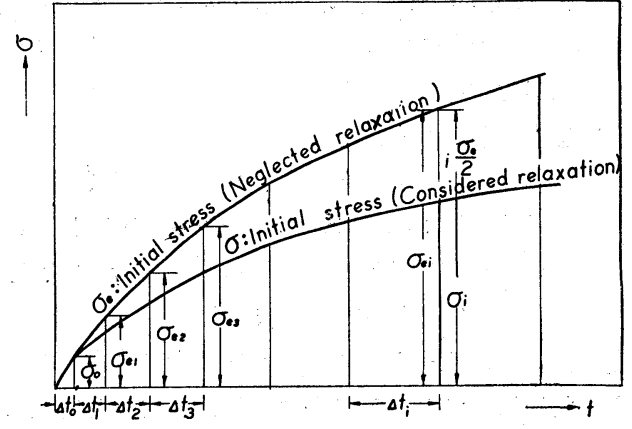

Fig. 3 Graphical computation of relaxation

By Maxwell's equation: $\frac{\partial \sigma}{\partial t}+\phi_{s} \sigma=\frac{\partial \sigma_{e}}{\partial t}$

$$
\begin{aligned}
& \Delta \sigma+\phi_{s} \sigma t=\Delta \sigma_{e} \\
& \text { When } \Delta t_{o}=\frac{1}{N \phi_{s}} \\
& \Delta \sigma+\frac{\sigma}{N}=\Delta \sigma_{e} \\
& \text { assumed } \sigma_{o}=\sigma_{e o}, \quad \Delta \sigma_{o}=\Delta \sigma_{e o}-\frac{\sigma_{o}}{N} \\
& \therefore \quad \sigma_{1}=\sigma_{o}+\Delta \sigma_{o}=\sigma_{o} e+\Delta \sigma_{e o}-\frac{\sigma_{n}}{N}=\sigma_{e 1}-\frac{\sigma_{o}}{N}
\end{aligned}
$$

When $\Delta t_{2}=N \phi_{s} \frac{\sigma_{n}}{\sigma_{1}}, \Delta \sigma_{1}=\Delta \sigma_{e 1}-\frac{\sigma_{n}}{N}$

$$
\sigma_{2}=\sigma_{1}+\Delta \sigma_{1}=\sigma_{e 1}+\Delta \sigma_{e 1}-2 \frac{\sigma_{n}}{N}=\sigma_{e 2}-2 \frac{\sigma_{n}}{N}
$$

$\sigma_{i}$ is obtained one after another

then, $\quad \sigma_{i}=\sigma_{e i}-i \frac{\sigma_{0}}{N}$ (in Fig. $3, N=2$ )

なお，収縮の進行および持続が長時間にわたるとき は，コンクリートのリラクセーションを考えなければ
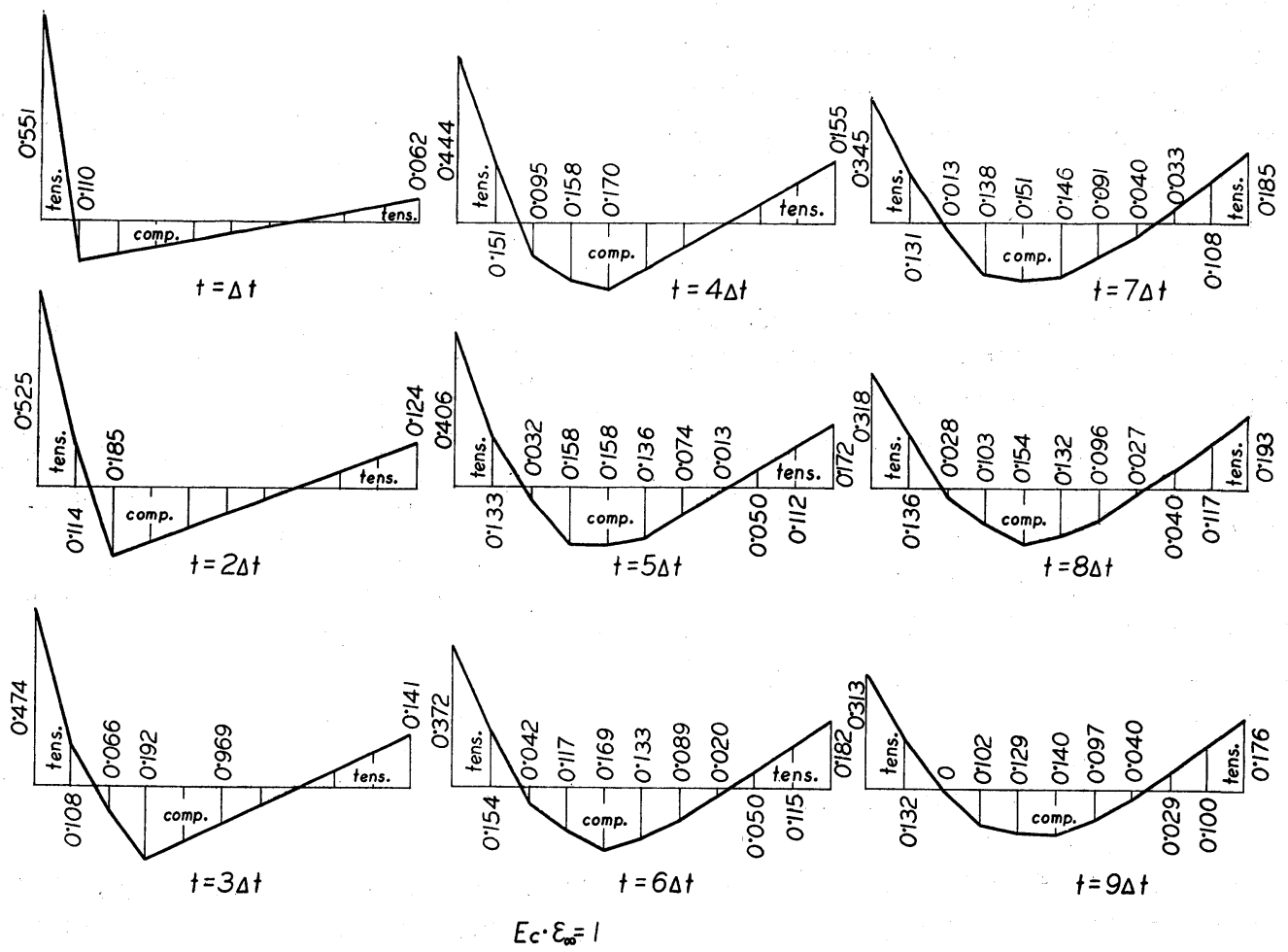

Fig. 4 Shrinkage distributions at each time (drying in air) assumed $E_{c} \cdot \varepsilon_{\infty}=1$ when $\Delta x=\frac{D}{10}, \frac{\lambda}{\alpha}=\Delta x$ (obtained by graphical method) 
ならない. Fig. 3 に示すように, Maxwell の方程式 を同じく差分方程式に変形すれば，これも図解的に行 なうことができるが，ここでは短時間での初応力の発 生持続を考えることにする.

厚さDのスラブを 10 等分し, $\Delta x=\frac{D}{10}$ のとき, $\lambda / \alpha=\Delta x$ として， $t=\Delta t, 2 \Delta t, 3 \Delta t, \cdots \cdots, 9 \Delta t$ におけ る乾燥収縮の分布を求めれば，Fig. 4 のとおりである.

\section{3. 初応力の実測}

実際にコンクリート中に生ずる初応力の大きさを測 定するために，つぎの二つの方法により実験を行なっ た.

a ) $40^{\circ} \mathrm{C}$, 風速約 $1 \mathrm{~m} / \mathrm{sec}$ 湿度は Fig. 5 中に示 す程度の空気中で, はり形供試体を一面だけから乾燥 させて, 表層に引張の初応力を発生させ, この供試体 と乾燥させないものとの曲げ強度の減少により, 初応 力の大きさを推定した.

b ） a )と同じ〈, 初応力を発生した供試体の乾燥 面を層状に切削すれば，切削部に作用していた初応力 は除かれて供試体は变形する。これを供試体各部に配 置した抵抗線ひずみ計で測定し，切削深さに対する変 形量から，その深さまで存在した初応力を測定した。

以下，各項について報告する.

a ）乾燥による供試体の強度低下

(1) 供試体：普通ポルトランドセメント,および 2 種高炉セメントを使用したモルタル，およびコンクリ 一卜 (骨材最大寸法 $10 \mathrm{~mm}$ ) 存用い，供試体寸法は $7 \cdot 5$ $\times 15 \times 53 \mathrm{~cm}$ である. 所定の日数水中で養生した供試 体は，1面のみを残し $(7 \cdot 5 \times 53 \mathrm{~cm}$ の面とした $)$ ，他 面にはラッカーを塗り，蒸発はその面からのみ行なわ れるようにした。

(2) 乾燥処理 : 乾燥は, 著者の研究室内の恒温恒湿 室で行ない, 気温 $40^{\circ} \mathrm{C}$, 風速約 $1 \mathrm{~m} / \mathrm{sec}$, 湿度, 普通 ポルトランドセメント使用のもの, $67 \pm 2 \%$, 高炉セ メント使用のもの， $53 \pm 2 \%$ とした。

(3) 破壊試験：乾燥面が引張側端縁となるように, スパン $45 \mathrm{~cm}, 3$ 等分点, 2 点荷重をアムスラ一型圧 縮試験機でかけて曲げ強度を求めた。

\section{4. 試 験 結 果}

使用したモルタル，およびコンクリート配合と，そ の供試体を乾燥した時間の長さと曲げ強度との関係を Fig. 5 に示す.

b ）切削法による初応力の測定

(1) 供試体および乾燥処理：a）とまったく同一で ある。また，使用配合は Fig. 6 中に示す。

(2) 切削: 乾燥させた恒温恒湿室内で行ない, 平刃 のたがねで，乾燥面をグージ幅の 3 倍だけ削った，各 回の切削深さは， $10 \mathrm{~mm}$ 前後としたが，これを常に一 定とすることは困難であって，その前後に多少違って

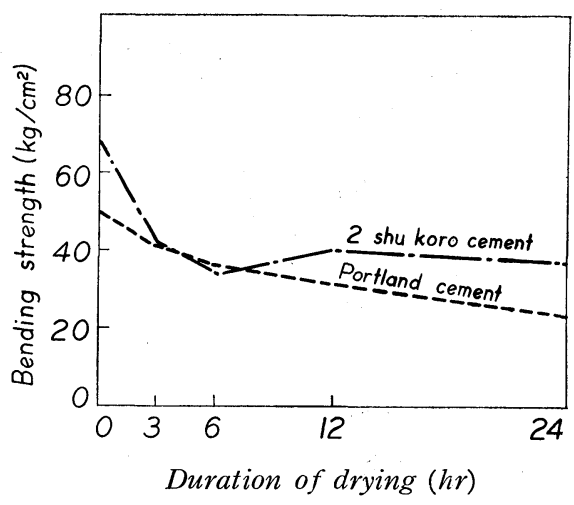

Fig. 5 (a) Relation between duration of drying and bending strength (by case of $1: 2$ mortar)

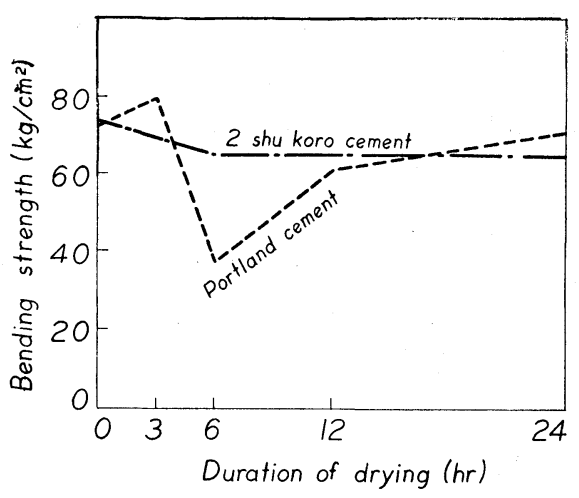

Fig. 5 (b) Relation between duration of drying and bending strength (by case of concrete)

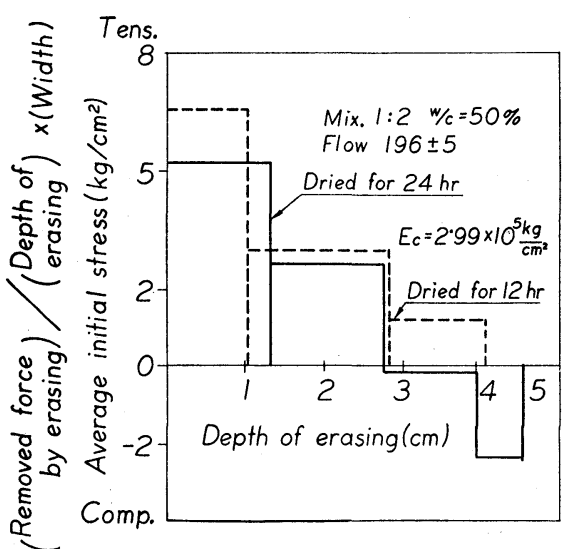

Fig. 6 (a) Distribution of average initial stress

いる．たがねでだいたい平坦に削った後，静かにとい しでこすって切削面を平面とし，もとの乾燥面に平行 にした.

(3) 变形の測定 : 乾燥面に相対する面の切削籄所に 


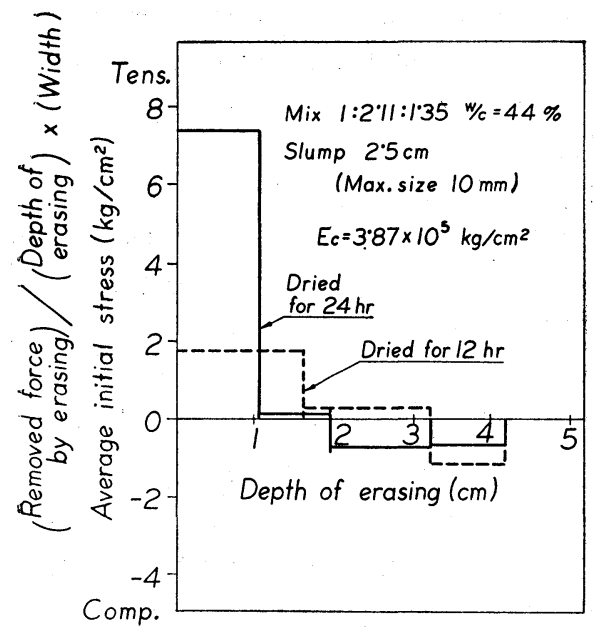

Fig. 6 (b) Distribution of average initial stress (Portland cement concrete)

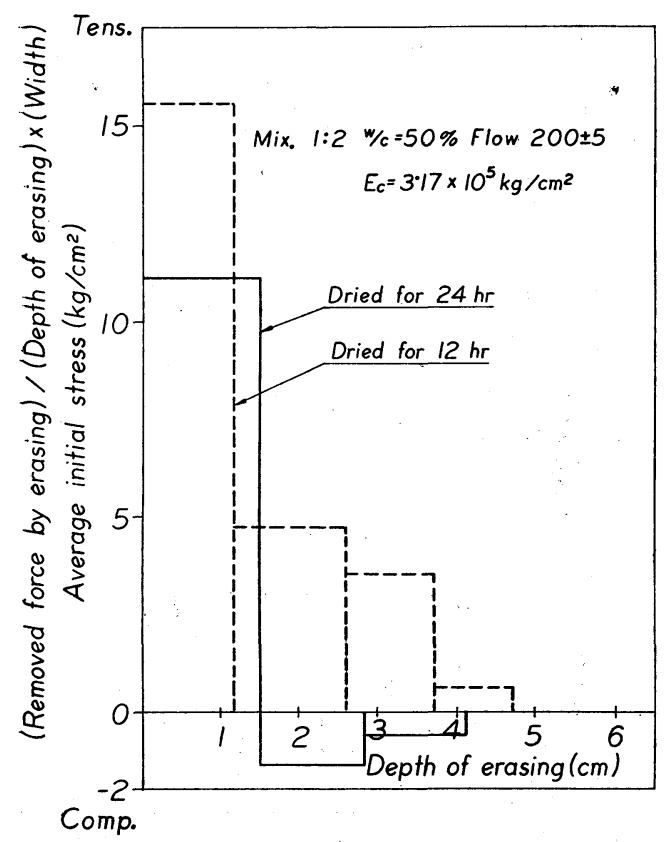

Fig. 6 (c) Distribution of average initial stress (2 shu slag cement mortar)

対する点, それより $2.5 \mathrm{~cm}$ 間隔に両側面 4 籄所, 計 5 枚のダージを Fig. 7 に示すように貼りつけ，供試 体および恒温室が $20^{\circ} \mathrm{C}$ に冷却した後, 静的測定用抵 抗線ひずみ計で補償ゲージとバランスさせ, 各回の切 削後にひずみを測定した. 約 $10 \mathrm{~mm}$ を切削するに要 する時間は 5 10 分程度である. なお, 冷却中は乾燥 面にもラッカーを叙った。

(4) 測定結果の解析 : 乾燥面を層状に切削して生ず る, 各点のひずみ測定值によると切削部中央を横断す る平面は, 変形後においても, だいたい平面である。

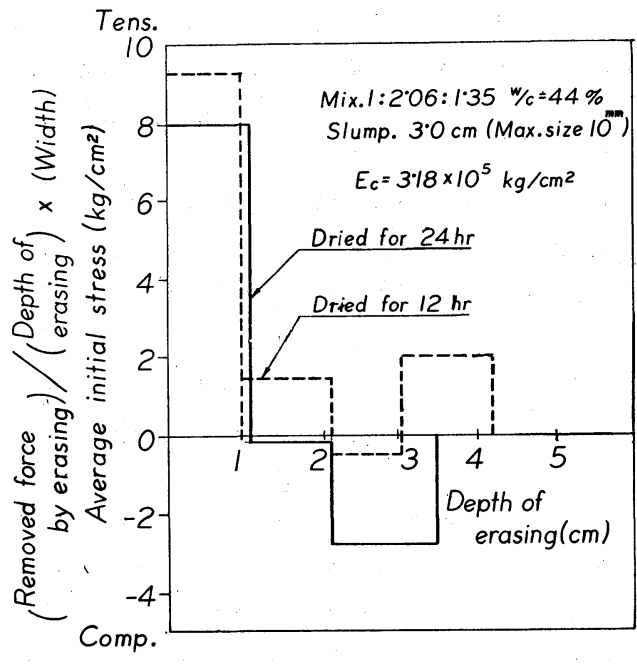

Fig. 6 (d) Distribution of average initial stress (2 shu slag cement concrete)

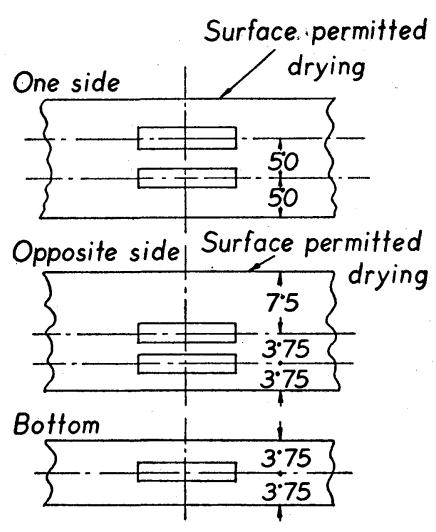

Note:unit is $\mathrm{cm}$

Fig. 7 Arrangement of strain-gauge on the surfaces of specimen

また，除かれた初応力の合力が表層にあれば，この断 面の中立軸は, 反対面側より $1 / 3$ 高さの点にある.し かし，実際には合力はそれよりやや内側にあるため， 中立軸の位置は $1 / 3$ 高さよりわずか反対面側にある. この関係は, 切削中の乾燥または切削操作そのものに よって, 切削深さ以上の内部の応力まで除かれてしま うような場合の判定の参考にした。だいたいにおいて， 中立軸の位置は切削前後表面より考えると, その反対 側面より $1 / 3$ 高さの点付近に認められたが, 切削の深 さが大となってくると，長時間経過する関係もあって， $1 / 3$ 高さの点よりはなれてくる傾向があり, そのいち じるしいものは測定を中止した.

切削によって除かれた力は, 供試体断面各位置に現 われた伸びと縮みを生ずるに必要な断面力に等しいも のであって，中立軸が前述のように切削面反対側より 


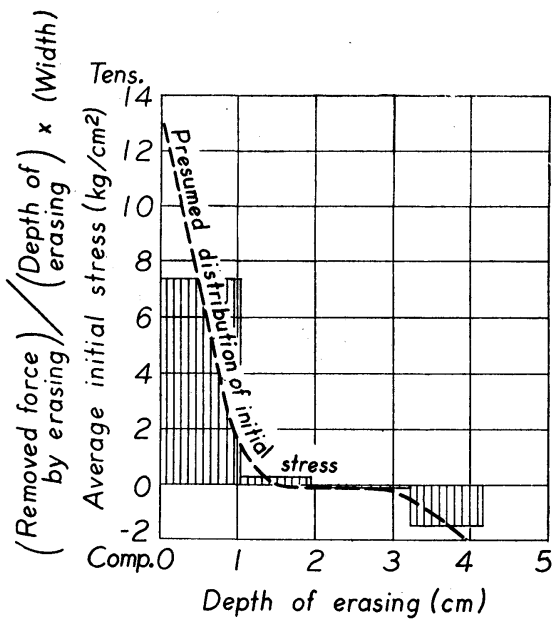

Fig. 8 Presumed distribution of initial stress

$1 / 3$ 高さの点付近にあって，反対面側に縮みが現われ るので, この場合引張力である.

(5) 測定結果 : Fig. 6 に切削深さと, その除かれた 力との関係を示す.この力の大きさは各切削梁さに存 在した力の平均であって, Fig. 8 に示すように破線で 示す曲線が初応力の実際に分布する形に近いであろう。

\section{4. 考察}

コンクリートは多くの場合, 普遍的な数值を出すこ とが困難であるが, 水分の蒸発, とくに，半結合水の 放散に関しては, 配合, セメント種類など, 数多くの 因子によって広い範囲に変化するので, 初応力の值は 非常にまちまちである。しかし，本実験から得られた 範囲では初応力の值は表面で $15 \mathrm{~kg} / \mathrm{cm}^{2}$ 程度の引張 り応力であった。乾燥条件を同じにしたとさの曲げ強 度の減少量から考えても, この程度の乾燥で生ずる初 応力は, このくらいの值と判定することができると思 う.

切削による実測值は, 表層より供試体厚さの約 $1 / 3$ 付近までしか求められていないが，これは金属と異な クコンクリートはこれ以上切削深さを增せば折れやす く，切削できないこと，および長時間経過するために， 内部の応力が変ることによるものである。また，供試
体の間の不均質性もあって, 金属材料の残留応力の場 合のように， 2 個の供試体をそれぞれ反対側から若干 オーバーラップするように切削して，その分布をつな ぎ合わすことはできなかった。

また，Fig. 4 に示す計算値は，本実験に用いたよう な厚さ $15 \mathrm{~cm}$, 風速 $1 \mathrm{~m} / \mathrm{sec}$, 温度 $40^{\circ} \mathrm{C}$, 湿度 $67 \%$ の場合は $\lambda=0.003(m h)^{-1}$ の水分伝播率のコンクリー トの乾燥の場合に相当する。これと実測值と比較して みると，そうとう時間乾燥したときの実測值でも, 乾 燥収縮の進行が, あまりコンクリート内部深くまで及 んでいないことを示している。すなおち，多くの場合， 表層での初応力分布曲線の勾配が急であり, 引張りか ら圧縮に変わる点が比較的表層近くに存在する。

乾燥収縮は, 自由水の放散後半結合水が失われて, はじめて現われるが，その中間では一部分自由水と， 半結合水の両者が同時に放散することもあって，時間 的経過が解析的方法によって得られたものと似ていな い場合もあるが，表層近くの分布状態はよく合ってい る. しかし，半結合水の放散開始時 $t=0$ をはっきり と定めることは現在のところ困難であるが, コンクリ 一ト構造物工事の設計, および施工においては, 初応 力はその最大値と，その発生箇所の推定ないし危険箇 所付近の分布状態が明確に推定できれば充分ではない かと思われる。とくに，セメント，骨材など，コンク リート材料によって, 初応力の最大值, および分布状 態が異なるので，初応力発生によるき裂を少なくする ための材料試験法として, 本研究はある程度有益であ ると思われる。

\section{参 考 文 献}

1）大浜文趁，坂村呆，セメント技術年報，319（昭31）

2) 大浜交避, 土木学会論文集，46，7(昭32)

3）大浜交展, 土地改良（昭32-7）

4) 大浜文產, 山口大学工学部学㪕, 4-1, 42 (昭28-10)

5）大浜文斑, 三重大学農学部学術報告，18，89（昭33-10）

6) Carlson R.W. Jour. ACI, 34 (1937)

7) Schmidt E, Fopples Festschrift (1924)

8) Prof. A.D. Ross and T.W. Bray, Magazine of Concrete Research, 9 (1949)

9）崕峨卓郎活か 2 名, 応用物理, 26-4（昭32）

10）川内雄一, 応力測定法, 358 (昭30-9), 朝倉書店 